\title{
Anti-aging Effect of Brazilin in UVA-irradiated Dermal Fibroblasts
}

\author{
Joong Hyun Shim \\ Department of Oriental Cosmetic Science, Semyung University, Jecheon-si, Chungcheongbuk-do, Korea
}

Corresponding author: Joong Hyun Shim, Department of Oriental Cosmetic Science, Semyung University, 65 Semyung-ro, Jecheonsi, Chungcheongbuk-do 27136, Korea

Tel.: +82436491615

Fax: +82 436491730

Email: jhshim@semyung.ac.kr

\section{Received March 14, 2016}

Revised April 26, 2016

Accepted May 23, 2016

Published September 30, 2016

\begin{abstract}
Purpose: This research was carried out to identify the skin anti-aging effect of brazilin on dermal fibroblasts. Methods: To investigate anti-aging effects of brazilin on dermal fibroblasts, we confirmed cell viability, mRNA expression, and ELISA assay (collagen, type I and MMP1). Results: In this study, we elucidated the effects of brazilin on mRNA expression (COL1A1, COL3A1, MMP1, SOD1, SOD2, SOD2, and $C A T$ ) and on protein production (collagen, type I and MMP1). Quantitative Realtime RT-PCR showed that brazilin increased mRNA expression of COL1A1, COL3A1 and SOD3 genes and protein production of collagen, type I compared with UVAtreated dermal fibroblasts. Furthermore MMP1 mRNA and protein expressions were decreased by brazilin treatment. These observations revealed that brazilin increased anti-aging effects in dermal fibroblasts. Conclusion: Therefore, we identified the anti-aging effects of brazilin, and this result showed that the brazilin can be a considerable potent ingredient for skin anti-aging. Based on this, we need to study further researches about mechanisms of brazilin to be developed for cosmetics, healthcare food, and medicine.
\end{abstract}

Keywords: Brazilin, Anti-aging, COL1A1, MMP1, SOD3

\section{Introduction}

피부는 외부 요인의 위해로부터 우리 몸의 항상성을 유지시 켜 주는 일차적인 보호기관이다. 또한 생물학적, 물리적, 화학적 장벽기능을 수행하고 있으나 인체의 최외각층에 존재하고 있어 다양한 외부 환경적 요인에 의해 손상을 받게 된다(Lee et al., 2007; Yoon et al., 2013). 외부 환경의 주요 스트레스 인자는 황사, 미세먼지 등의 오염물질, 자외선, 미생물의 번식 등을 대 표적인 예라 할 수 있으며 이들은 활성산소종(reactive oxygen species, ROS)을 생성하여 피부를 구성하는 세포의 손상과 사멸 을 유도하고 피부의 건조, 주름생성, 탄력저하 등의 피부 노화를 가속화 시킨다(Kim et al., 2011; Yoon et al., 2013).

피부 노화는 크게 내인성 노화와 외인성 노화로 구분되는 데, 내인성 노화는 신체를 구성하는 모든 기관의 자연적인 퇴 화과정에 의해 진행되는 노화이고 외인성 노화는 광노화와 같이 외부환경의 인자에 노출되었을 시 발생하는 노화이다 (Gilchrest, 1996; Chung et al., 2002). In vitro 상에서 배양
중인 섬유아세포에 자외선을 조사하거나 생체 조직에 직접적 으로 자외선이 조사되면 matrix metallopeptidases (MMPs) 의 발현이 증가하고 콜라겐의 생성이 감소되어 피부 진피층 의 결합조직이 손상을 받게 된다(Brenneisen et al., 2002; Chung et al., 2002; Moon et al., 1992). 또한 ultraviolet A (UVA)와 ultraviolet B (UVB)는 DNA 손상 및 활성산소종 을 생성시켜 세포사멸을 유도하고(Assefa et al., 2005), 이 로 인해 직접적 혹은 간접적으로 염증반응, 광감작, 암화 등 을 유도한다(Bickers \& Athar, 2006). 피부는 항상 자외선 에 노출되어 있을 뿐 아니라 대기 중의 산소가 직접 전달되기 때문에 활성산소종이 과도하게 생성되기 쉽다. 자외선 노출 이 반복되었을 때 superoxide dismutases (SODs), catalase (CAT), glutathione peroxidases (GPXs) 등과 같은 항산화 효소의 변성에 의한 항산화 시스템의 불균형이 초래될 수 있다 (Moysan et al., 1993; Poswig et al., 1999).

브라질린(Brazilin; 7, 11b-dihydrobenz[b]indeno[1, 2-d] pyran-3, 6a, 9, 10 (6H)-tetrol)은 인도, 말레이시아, 중국 남 
부 등의 열대 아시아에 분포하는 콩과 식물인 소목(Caesalpinia sappan L.)의 주성분으로 알려져 있다. 또한 천연의 적색 색소 로, 염료나 산 및 알칼리 지시약 또는 식품 첨가물 등으로 사용해 왔다(Puchtler et al., 1986). 최근의 연구결과에서는 어혈에 의 한 타박손상, 월경폐색, 고혈압, 혈당저하, 항균작용, 항염작용 등의 다양한 생물학적 효능을 지녔다고 보고되었다(Moon et al., 1992; Hwang et al., 1998; Bae et al., 2005).

브라질린이 UVA에 의해 노화가 유도된 진피 섬유아세포에 서 피부 노화 개선에 효능이 있는지에 대한 연구는 전무한 실정 이다. 본 연구에서는 브라질린의 항노화 효능과 관련하여 섬유 아세포의 표지인자인 COL1A1과 COL $3 A 1, M M P 1$ 유전자 발 현에 미치는 영향을 확인해 보고, 자외선 조사에 의해 감소된 섬유아세포의 collagen, type I 단백질의 생산 능력과 자외선 조사에 의해 증가된 MMP1 단백질의 생산 능력이 브라질린에 의해 회복되는지 입증하고자 한다. 또한 자외선 조사에 의해 변 화된 섬유아세포의 항산화 시스템이 브라질린에 의해 회복되는 지의 여부를 확인하고자 한다. 이를 통해 브라질린의 향후 항노 화 화장품 및 바이오 소재로서의 가능성을 제시하고자 한다.

\section{Methods}

\section{1. 실험재료 및 세포배양}

섬유아세포(normal human dermal fibroblast)는 Cell Application Inc. (USA)에서 구매하여 사용하였으며, 세포배 양을 위한 Dulbecco's modified Eagle's medium (DMEM), fetal bovine serum (FBS)는 Welgene Inc. (Korea)에서, 항 생제(penicillin/streptomycin)는 Invitrogen (USA)에서 구 입하여 사용하였다. 세포처리에 사용된 브라질린은 Wuhan ChemFaces Biochemical Co., Ltd. (China)에서 구입하였다. 섬유아세포는 $37^{\circ} \mathrm{C}$ 로 유지되고 $5 \% \mathrm{CO}_{2}, 100 \%$ 습윤배양기에서 배양하였다.

\section{2. 자외선 조사}

UVA 조사로 섬유아세포의 노화를 유도하기 위해서 하기와 같 은 조건으로 UVA를 조사하였다. 섬유아세포가 배양되고 있는 35 $\mathrm{mm}$ 조직배양접시에 phenol red가 첨가되지 않은 $1 \mathrm{~mL}$ 의 $\mathrm{DMEM}$ 을 접종한 후, 자외선 조사장치(BioLink; Vilber Lourmat, Germany)를 사용하여 $7 \mathrm{~J} / \mathrm{cm}^{2}$ 의 UVA를 조사하였다.

\section{3. 세포 생존율 측정}

세포 생존율은 cell counting kit-8 (CCK-8; Dojindo, Japan) 분석법을 이용하였다. 섬유아세포를 조직배양접시에 접종한 후 브라질린을 농도별로 처리하였다. 브라질린을 농 도별로 처리한 섬유아세포를 $24 \mathrm{~h}$ 배양한 후 CCK-8 시약을 첨가하여 $0.5 \mathrm{~h}$ 동안 $5 \% \mathrm{CO}_{2}, 37^{\circ} \mathrm{C}$ 배양기에서 배양하였다. ELISA reader (BioTek, USA)를 사용하여 $450 \mathrm{~nm}$ 에서 흡광 도를 측정하였으며, 세포를 첨가하지 않고 배지만 넣은 대조군 의 흡광도를 기준으로 세포 생존율을 산출하였다.

\section{RNA 추출 및 실시간 유전자 중합효소 연쇄반응(Quantitative Real-time RT-PCR)}

Thermo Scientific사의 TRIzol Reagent (USA)를 사용 하여 RNA를 추출하였다. 추출한 RNA로부터 $\mathrm{cDNA}$ 의 합성 은 ReverTra Ace $\alpha$ 역전사효소 키트(Toyobo, USA)를 사용 하여 합성하였으며, 섬유아세포 표지인자와 항산화효소의 발 현을 비교 측정하기 위하여 Real-time RT-PCR (Applied Biosystems, USA)을 진행하였다. 실험에 사용된 특정 Taqman Gene expression assay는 Table 1에 표기하였다.

\section{5. 효소결합면역흡착법(enzyme-linked immunosorbent assay, ELISA)}

브라질린이 collagen, type I과 MMP1 단백질 생성에 미치 는 영향을 알아보기 위하여 섬유아세포를 $24 \mathrm{~h}$ 동안 $5 \% \mathrm{CO}_{2}$, $37^{\circ} \mathrm{C}$ 배양기에서 전 배양한 후, 자외선 조사기를 통해 $7 \mathrm{~J} /$ $\mathrm{cm}^{2}$ 의 UVA를 조사하였다. 조사 후 $2 \mu \mathrm{g} / \mathrm{mL}$ 농도의 브라질

Table 1. Gene name and assay ID number in Quantitative Real-time RT-PCR analysis

\begin{tabular}{lll}
\hline Symbol & Gene name & Assay ID \\
\hline COL1A1 & Collagen type I alpha 1 chain & Hs00164004_m1 \\
COL3A1 & Collagen type III alpha 1 chain & Hs00943809_m1 \\
MMP1 & Matrix metallopeptidase 1 (interstitial collagenase) & Hs00899658_m1 \\
SOD1 & Superoxide dismutase 1, soluble & Hs00533490_m1 \\
SOD2 & Superoxide dismutase 2, mitochondrial & Hs00167309_m1 \\
SOD3 & Superoxide dismutase 3, extracellular & Hs00162090_m1 \\
CAT & Catalase & Hs00156308_m1 \\
GAPDH & Glyceraldehyde-3-phosphate dehydrogenase & 43333764F \\
\hline
\end{tabular}


A

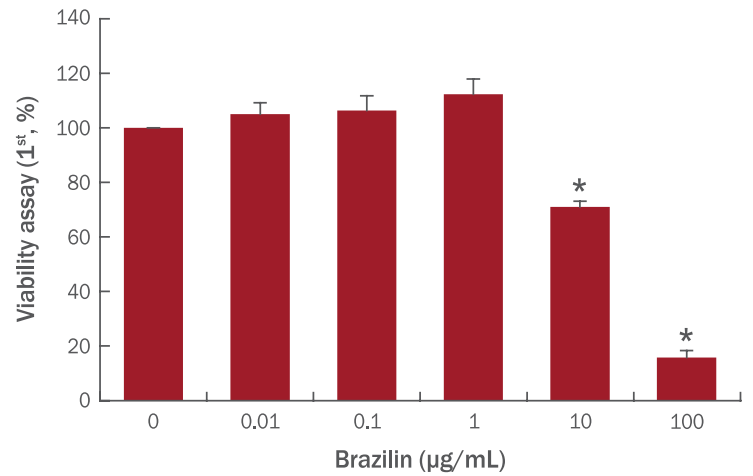

B

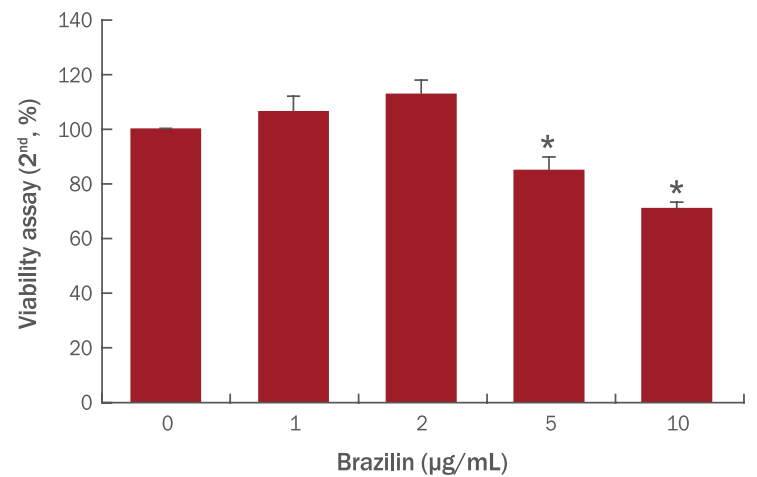

Figure 1. Cytotoxicity aspects of brazilin in dermal fibroblasts. Dermal fibroblasts $\left(2 \times 10^{3}\right.$ cells) were seeded in 96-well plate and treated with indicated concentrations of brazilin for 24 h. Cell viability was measured by CCK- 8 assay. The results are presented as the mean \pm S.D. of the percentage of control optical density (OD) in triplicate (A, B). * means compared to control $\left({ }^{*} p<.05\right)$.

린을 첨가하여 $48 \mathrm{~h}$ 동안 배양하였다. Procollagen type I C-peptide-ELISA kit (Takara Bio, Japan)와 MMP1ELISA kit (R\&D Systems, USA)를 이용하여 제조사의 프로 토콜을 따라 섬유아세포가 분비하는 배양액 내의 collagen, type I과 MMP1의 양을 측정하였다.

\section{6. 통계분석}

데이터는 평균 \pm 표준편차로 표현하였으며, 통계처리는 Student's t-test 법을 이용하여 각 구간의 유의성 차이를 유의 수준 $0.05(p<.05)$ 로 하여 검정하였다.

\section{Results \& Discussion}

\section{1. 브라질린 농도별 섬유아세포의 생존율 분석}

섬유아세포에 대한 브라질린의 세포독성에 대한 영향을 확 인하기 위하여 CCK-8 assay를 실시하였다. 대조군은 시료를
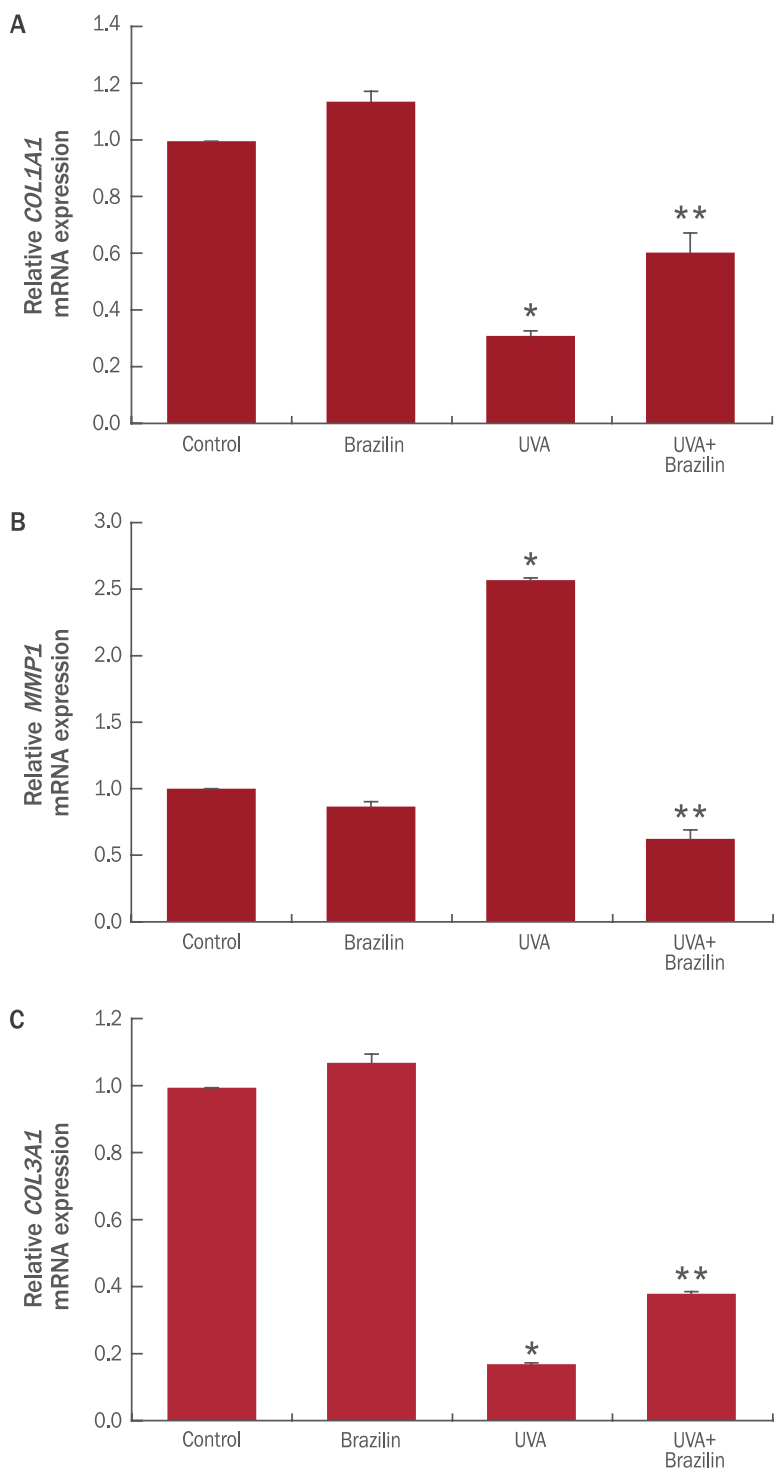

Figure 2. Characterization of brazilin treatment on UVAirradiated dermal fibroblasts.

Quantitative real-time RT-PCR analysis of the dermal fibroblast markers, COL1A1 (A), MMP1 (B), and COL3A1 (C). The left panel, represented as Control, shows a bar graph of mRNA expression levels in non-treated dermal fibroblast cells both brazilin and UVA. The panel in the second, shown as brazilin, depicts mRNA expression levels in brazilintreated dermal fibroblast cells, without UVA irradiation. The panel in the third, represented as UVA, indicates mRNA expression levels in UVA-irradiated dermal fibroblast cells, except brazilin treatment. The panel on the right hand, shown as UVA+brazilin, describes mRNA expression levels in dermal fibroblast cells, treated both UVA and brazilin. Values represent the mean \pm S.D. of three independent experiments. * means compared to control, and ${ }^{* *}$ means compared to UVA-irradiated condition $\left({ }^{*},{ }^{* *} p<.05\right)$. 
처리하지 않았고 브라질린은 $0.01,0.1,1,10,100 \mu \mathrm{g} / \mathrm{mL}$ 의 농도 로 처리하여 세포생존율을 측정하였다(Figure 1A). $10 \mu \mathrm{g} / \mathrm{mL}$ 이 상의 농도를 처리할 때 섬유아세포의 생존율이 유의성 있게 감소하 여, 추가적으로 $10 \mu \mathrm{g} / \mathrm{mL}$ 과 $1 \mu \mathrm{g} / \mathrm{mL}$ 의 농도를 세분화하여 CCK-8 assay를 수행하였다(Figure 1B). $5 \mu \mathrm{g} / \mathrm{mL}$ 이상의 농도를 처리할 때 섬유아세포의 생존율이 유의성 있게 감소하였다. $2 \mu \mathrm{g} / \mathrm{mL}$ 의 농도 로 처리시에는 섬유아세포의 생존율이 대조군과 비교하여 유사함을 확인하여 본 실험에서는 $2 \mu \mathrm{g} / \mathrm{mL}$ 의 브라질린을 처리하여 추가실험 을 진행하였다.

\section{2. 자외선 조사와 브라질린 처리에 따른 섬유아세포의 mRNA 발현}

자외선은 파장의 길이에 따라 UVA (장파장, 320-400 nm), UVB (중파장, 290-320 nm), UVC (단파장, 200-290 nm) 로 구분된다(Lee et al., 2007; Kim et al., 2011). 본 실험에 서는 피부의 진피층까지 침투하여 외인성 노화를 유발하는 $\mathrm{UVA}$ 를 실험에 사용하여 섬유아세포의 노화를 유도하였다. 섬유아세포에 $7 \mathrm{~J} / \mathrm{cm}^{2}$ 의 UVA를 한 차례 조사한 후 $2 \mu \mathrm{g} / \mathrm{mL}$ 의 브라질린을 처리하여 섬유아세포가 발현하는 표지인자인 $C O L 1 A 1, C O L 3 A 1, M M P 1$ 의 발현양을 실시간 유전자 중합 효소 연쇄반응을 통하여 확인하였다. 자외선 조사에 의해 섬 유아세포는 COL1A1,COL3A1과 같은 섬유아세포의 표지인 자의 발현이 감소하는 반면 $M M P 1$ 의 발현은 증가한다. 자외 선 조사 후 브라질린을 처리하고 실시간 유전자 중합효소 연 쇄반응을 통하여 섬유아세포의 표지인자 발현을 확인한 결과, 자외선 처리군 대비 COL1A1의 발현이 2배, COL $3 A 1$ 의 발 현이 2.25배 가량 증가하는 효과를 보였다(Figure 2A, 2C). $M M P 1$ 의 경우, 자외선 처리군 대비 $75 \%$ 감소하는 효과를 보 였다(Figure $2 \mathrm{~B}$ ). 이 결과를 통해 브라질린은 진피층의 1,3 형 콜라겐과 같은 세포외기질의 생성을 유도하며, 세포외기 질의 변성 및 분해를 유도하는 효소의 발현을 감소시켜 항노 화의 효과가 있는 소재라고 보여진다. 이는 브라질린이 진피 섬유아세포에서의 피부 노화 개선에 대한 최초의 연구로 새 로운 피부 노화개선 후보물질로서의 가능성을 보여준다. 위 상차 현미경으로 대조군, 브라질린 처리군, 자외선 처리군, 자외선 조사 후 브라질린 처리군의 섬유아세포 모양을 확인 시 별다른 차이는 보이지 않았다(Figure 3).

\section{3. 브라질린의 collagen, type I 생성 촉진 및 MMP1 생성 감소 효과}

브라질린을 처리하여 COL1A1 mRNA의 발현량이 증가 된 섬유아세포에서 collagen, type I 단백질의 생성 역시 증 가되는지를 알아보기 위해 collagen, type I에 대한 효소결합 면역흡착법(ELISA)를 사용하여 측정하였다(Figure 4A). 실 험결과, 자외선 조사에 의해 $28 \%$ 가량 생성이 감소되었던 collagen, type I이 브라질린 처리에 의해 자외선 처리군 대비

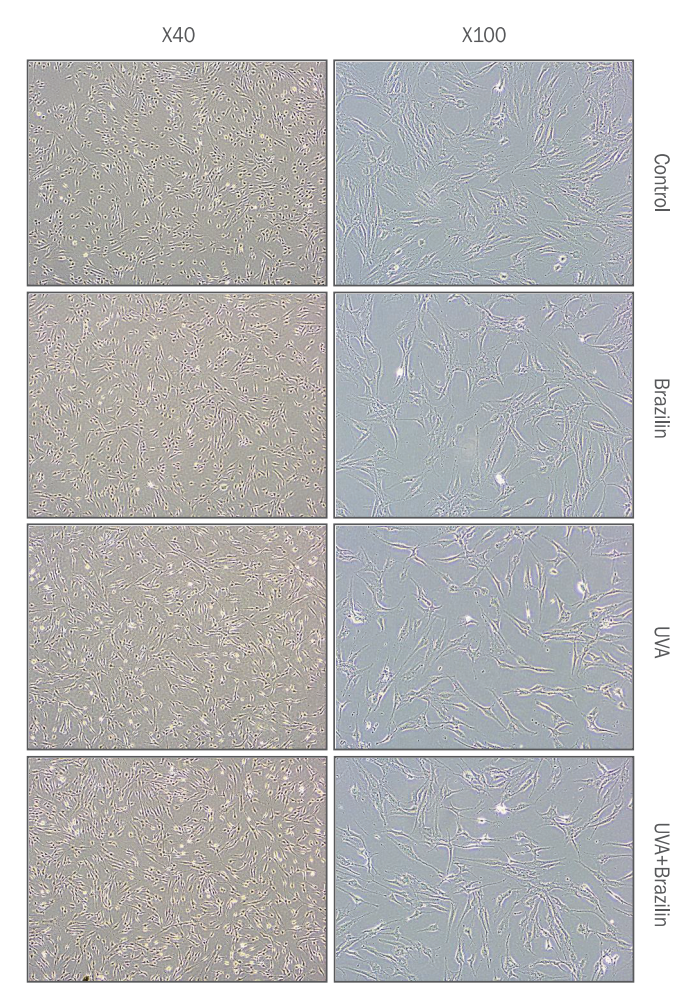

Figure 3. Morphological aspects of brazilin in dermal fibroblasts.

Dermal fibroblasts $\left(1.5 \times 10^{5}\right.$ cells $)$ were seeded in 6-well plate and treated with UVA or brazilin for $24 \mathrm{~h}$. Cell morphologies were confirmed by a phase-contrast microscope. However, there are no morphological differences among them.

$23 \%$ 가량 증가함을 확인하였다. 또한 브라질린 처리에 의해 $M M P 1 \mathrm{mRNA}$ 의 발현이 감소된 섬유아세포에서 MMP1 단백 질의 생성 역시 감소되는지 확인하기 위해 $\mathrm{MMP} 1$ 에 대한 효소 결합면역흡착법을 사용하여 확인하였다. 실험결과, 자외선 조 사에 의해 $61 \%$ 가량 생성이 증가되었던 MMP1이 브라질린 처 리에 의해 자외선 처리군 대비 $30 \%$ 가량 감소됨을 확인하였다 (Figure 4B). 이 결과는 COL1A1과 MMP1 mRNA에 대한 실 시간 유전자 중합효소 연쇄반응의 실험 결과와 동일한 경향성 을 지니며, 브라질린은 $\mathrm{mRNA}$ 의 발현에 영향을 미칠 뿐 아니 라 단백질 생성에서도 일관성 있는 항노화 효능을 지닌다고 볼 수 있다.

\section{4. 브라질린의 항산화효소 발현에 대한 효과}

$\mathrm{UV}$ 조사에 의해 생성되는 활성산소는 $\mathrm{MMP} 1$ 등의 세포외 기질 분해효소의 발현을 유도하는 초기신호로 알려져 있다 (Brenneisen et al., 2002). 브라질린은 폴리페놀 계통의 물질 로, 강력한 항산화 효과가 있다고 알려져 있기 때문에 자외선 처리에 의해 변화하는 항산화효소의 발현을 조절하는지의 여부 

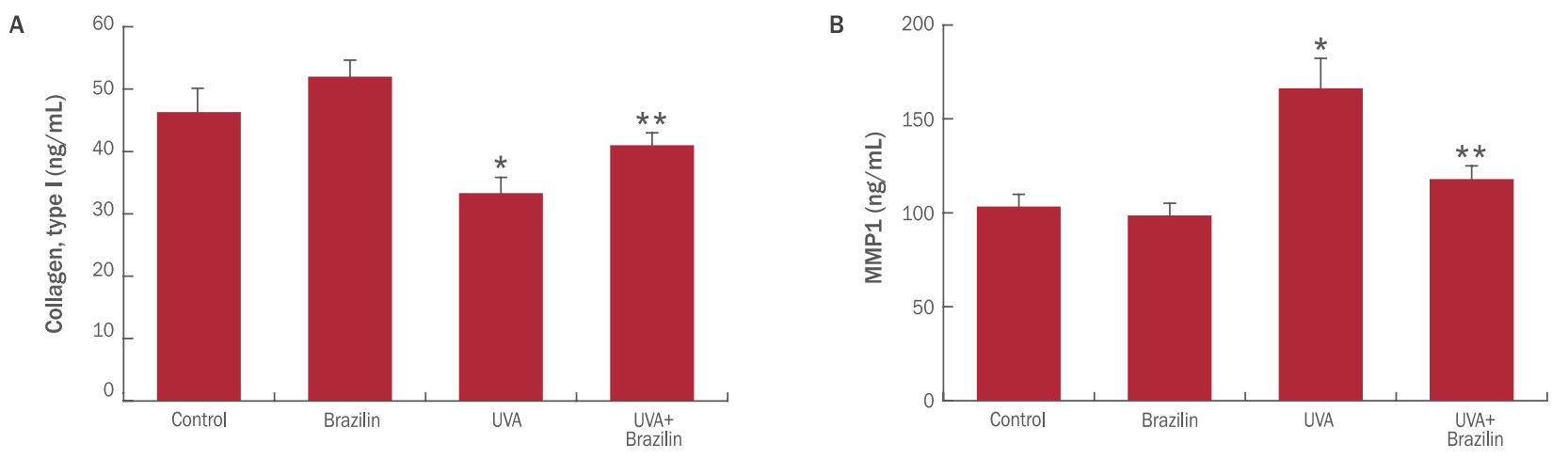

Figure 4. Effects of brazilin on collagen, type I and MMP1 synthesis in dermal fibroblasts.

Dermal fibroblasts were seeded in $60 \mathrm{~mm}$ culture dish, treated with brazilin for $48 \mathrm{~h}$. Cell culture media of the cells were collected and analyzed for collagen, type I (A) or MMP1 (B) by ELISA assay. The data represent the mean \pm S.D. of three independent experiments. " means compared to control, and ${ }^{* *}$ means compared to UVA-irradiated condition $\left({ }^{*},{ }^{* *} p<.05\right)$.
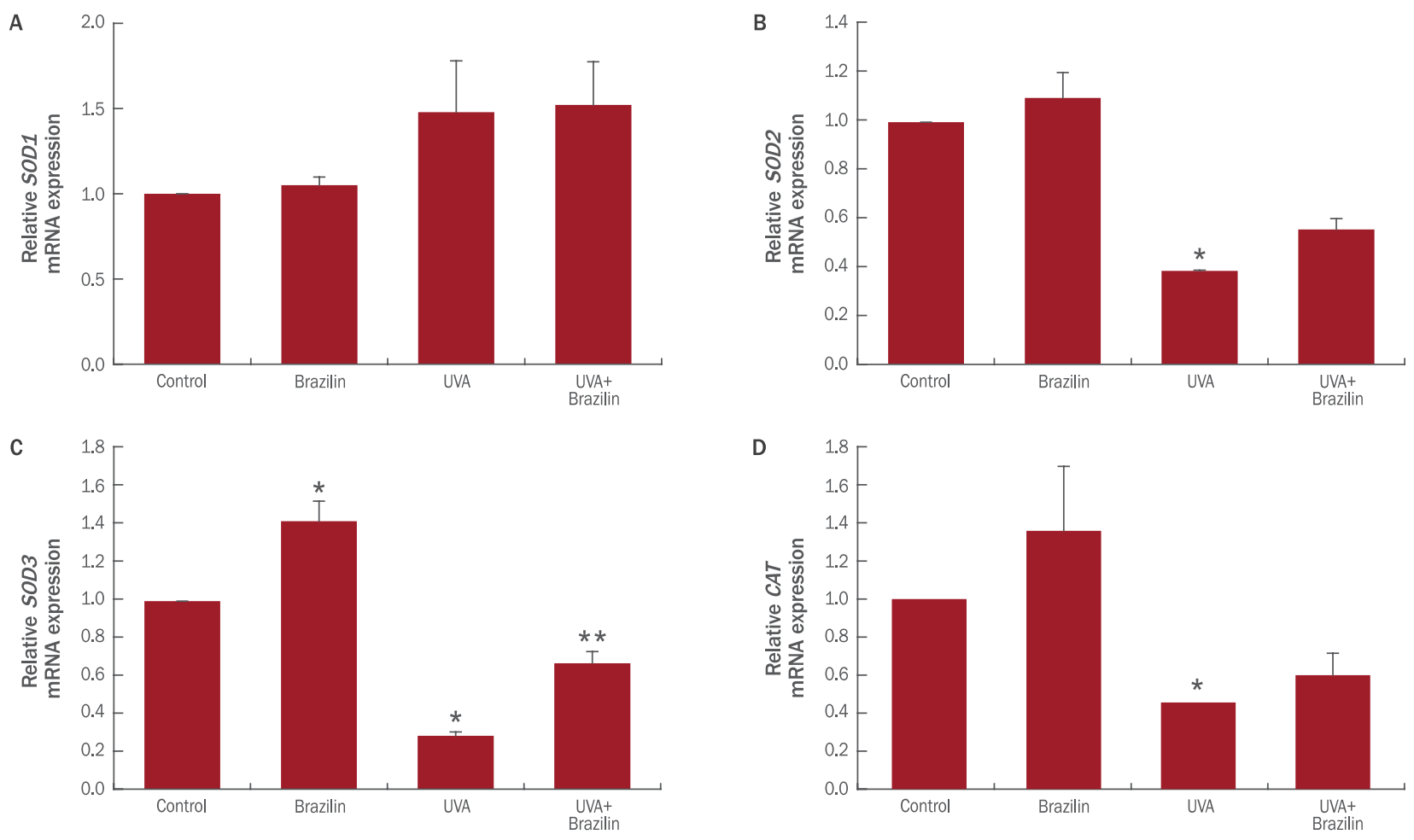

Figure 5. Anti-oxidant enzyme expressions of brazilin treatment on UVA-irradiated dermal fibroblasts.

Quantitative real-time RT-PCR analysis was conducted to measure the expressions of the representative anti-oxidant enzyme markers such as SOD1 (A), SOD2 (B), SOD3 (C), and CAT (D). The graphs are shown as the mean \pm S.D. of three independent experiments. " means compared to control, and ${ }^{* *}$ means compared to UVA-irradiated condition $\left({ }^{*},{ }^{* * *} p<.05\right)$.

를 확인하기 위하여 본 실험을 진행하였다(Lee et al., 2012). 본 실험에서는 섬유아세포에 UVA를 조사한 후 브라질린을 처 리하고 대표적인 항산화효소로 알려진 SOD1, SOD2, SOD3, $C A T$ 유전자의 발현을 실시간 유전자 중합효소 연쇄반응으로 확인하였다. 자외선에 의해 $S O D 2, S O D 3, C A T$ 유전자의 발
현이 유의적으로 감소하였고 여기에 브라질린을 처리하게 되면 SOD3 유전자가 특이적으로 그 발현이 자외선 처리군 대비 2.35 배 증가함을 확인할 수 있다(Figure 5). 이는 자외선이 SOD3의 유전자 발현을 감소시키지만 브라질린이 유전자의 발현을 회복 시킴을 보여준다. SOD3는 세포외기질로 분비되는 형태의 항산화 
효소로, Knockout 모델에서의 연구에서 $S O D 3$ 의 유전자발현 억제 에 의해 $\mathrm{SOD} 1,2$ 와 같은 항산화효소의 발현이 보상적으로 증가 되지 않는다고 알려져 있다(Carlsson et al., 1995). 반면 SOD3 과발현을 유도한 형질전환 마우스에서는 정상 마우스에 비해 산 화스트레스에 의한 DNA의 손상이 적고, 피부암의 발생빈도가 현저히 감소된다고 알려져 있는 바 추후, 피부 항노화에 SOD3 가 미치는 영향과 브라질린이 $S O D 3$ 의 유전적 발현에 미치는 효 과에 대한 심도있는 연구가 필요할 것이다(Kim et al., 2005).

\section{Conclusion}

일상생활에서 접하는 자외선은 살균작용, 비타민 D 합성 등 의 유익한 기능이 있으나, 또 다른 측면에서는 주름생성, 탄력 저하, 색소침착, 피부홍반, 염증 등의 증상을 유발하고, 활성 산소종의 연쇄 반응을 통해 노화를 진행시킨다(Talwar et al., 1995; Kim et al., 2011). 또한 자외선과 같은 환경적 요인에 의한 노화는 생체 내 존재하는 구성세포의 감소, 혹은 기능저 하를 유도하여 조직이 정상적으로 기능하거나 재생되지 못하 게 한다(Kirkwood, 2005; Jones \& Rando, 2011).

본 연구를 통해 브라질린을 섬유아세포에 처리할 적절한 농도를 확인할 수 있었다. $2 \mu \mathrm{g} / \mathrm{mL}$ 의 농도에서는 세포의 생존율에 영향을 미치지 않음을 Figure 1에서 확인하였다. $C O L 1 A 1$ 과 COL $3 A 1$ 의 유전자 발현 측정과 collagen, type I 단백질 발현 측정에서 브라질린이 자외선에 의해 감소된 섬유 아세포의 표지인자 발현을 유의성 있게 회복시키는 결과를 나 타내었다(Figure 2, 4). 반면 자외선에 의해 증가된 $M M P 1$ 은 브라질린에 의해 감소되는 결과를 나타내었다. 추가적으로 브 라질린이 MMP1 등의 세포외기질 분해효소의 활성을 유도하 는 활성산소를 조절하는 항산화효소 SOD3를 증가시킴을 확인 하였다(Figure 5). 이러한 결과를 바탕으로 브라질린이 새로 운 피부 노화개선 후보물질로서의 가능성을 보여준다.

본 연구를 통해 브라질린이 UVA에 의한 피부노화를 개선하 는 효과를 확인한 동시에 피부미용 및 피부노화 예방에 실질적 인 응용가능성을 제시하였다. 추가적으로 브라질린이 어떠한 신호전달 기전을 통해 자외선에 의해 노화된 섬유아세포를 개 선하는지에 대한 연구와 심도 있는 임상연구가 필요할 것으로 보인다.

\section{Acknowledgements}

이 논문은 2015학년도 세명대학교 교내학술연구비 지원에 의해 수행된 연구임.

\section{References}

Assefa Z, Van Laethem A, Garmyn M, Agostinis P. Ultraviolet radiation-induced apoptosis in keratinocytes: on the role of cytosolic factors. Biochimica et Biophysica Acta, 1755: 90-106, 2005.

Bae IK, Min HY, Han AR, Seo EK, Lee SK. Suppression of lipopolysaccharide-induced expression of inducible nitric oxide synthase by brazilin in RAW 264.7 macrophage cells. European Journal of Pharmacology, 513: 237-242, 2005.

Bickers DR, Athar M. Oxidative stress in the pathogenesis of skin disease. Journal of Investigative Dermatology, 126: 2565-2575, 2006.

Brenneisen P, Sies H, Scharffetter-Kochanek K. Ultraviolet-B irradiation and matrix metalloproteinases: from induction via signaling to initial events. Annals of the New York Academy of Sciences, 973: 31-43, 2002.

Carlsson LM, Jonsson J, Edlund T, Marklund SL. Mice lacking extracellular superoxide dismutase are more sensitive to hyperoxia. Proceedings of the National Academy of Sciences of the United States of America, 92: 62646268, 1995.

Chung JH, Seo JY, Lee MK, Eun HC, Lee JH, Kang S, Fisher GJ, Voorhees JJ. Ultraviolet modulation of human macrophage metalloelastase in human skin in vivo. Journal of Investigative Dermatology, 119: 507-512, 2002.

Gilchrest BA. A review of skin ageing and its medical therapy. British Journal of Dermatology, 135: 867-875, 1996.

Hwang GS, Kim JY, Chang TS, Jeon SD, So DS, Moon CK. Effects of brazilin on the phospholipase A2 activity and changes of intracellular free calcium concentration in rat platelets. Archives of Pharmacal Research, 21: 774778, 1998.

Jones DL, Rando TA. Emerging models and paradigms for stem cell ageing. Nature Cell Biology, 13: 506-512, 2011.

Kim J, Lee CW, Kim EK, Lee SJ, Park NH, Kim HS, Kim HK, Char K, Jang YP, Kim JW. Inhibition effect of Gynura procumbens extract on UV-B-induced matrixmetalloproteinase expression in human dermal fibroblasts. Journal of Ethnopharmacology, 137: 
427-433, 2011.

Kim SH, Kim MO, Gao P, Youm CA, Park HR, Lee TS, Kim KS, Suh JG, Lee HT, Park BJ, et al. Overexpression of extracellular superoxide dismutase (EC-SOD) in mouse skin plays a protective role in DMBA/TPA-induced tumor formation. Oncology Research, 15: 333-341, 2005.

Kirkwood TB. Understanding the odd science of aging. Cell, 120: 437-447, 2005.

Lee HY, Kim GJ, Kim YS, Lee SN, Lee SO. Skin science. Koonja Publishing, Paju, pp20-24, 2007.

Lee YR, Noh EM, Han JH, Kim JM, Hwang JK, Hwang BM, Chung EY, Kim BS, Lee SH, Lee SJ, et al. Brazilin inhibits UVB-induced MMP-1/3 expressions and secretions by suppressing the NF-KB pathway in human dermal fibroblasts. European Journal of Pharmacology, 674: 80-86, 2012.

Moon CK, Park KS, Kim SG, Won HS, Chung JH. Brazilin protects cultured rat hepatocytes from $\mathrm{BrCCl}_{3}$-induced toxicity. Drug and Chemical Toxicology, 15: 81-91, 1992.

Moysan A, Marquis I, Gaboriau F, Santus R, Dubertret L, Morlière P. Ultraviolet A-induced lipid peroxidation and antioxidant defense systems in cultured human skin fibroblasts. Journal of Investigative Dermatology, 100: 692-698, 1993.
Poswig A, Wenk J, Brenneisen P, Wlaschek M, Hommel C, Quel G, Faisst K, Dissemond J, Briviba K, Krieg T, et al. Adaptive antioxidant response of manganesesuperoxide dismutase following repetitive UVA irradiation. Journal of Investigative Dermatology, 112: 13-18, 1999.

Puchtler H, Meloan SN, Waldrop FS. Application of current chemical concepts to metal-hematein and -brazilein stains. Histochemistry, 85: 353-364, 1986.

Talwar HS, Griffiths CE, Fisher GJ, Hamilton TA, Voorhees JJ. Reduced type I and type III procollagens in photodamaged adult human skin. Journal of Investigative Dermatology, 105: 285-290, 1995.

Yoon Y, Bae S, An S, Choe YB, Ahn KJ, An IS. Effects of ultraviolet radiation on the skin and skin cell signaling pathways. Asian Journal of Beauty and Cosmetology, 11: 417-426, 2013. 


\section{국문초록}

\section{자외선 조사에 의해 노화된 섬유아세포에서 브라질린의 항노화 효능}

심중현

세명대학교 한방화장품과학과, 충청북도 제천시, 한국

목적: 본 연구는 브라질린이 자외선에 의해 노화가 유도된 섬유아세포의 항노화 효과를 확인하기 위하여 수행되었다. 방법: 자외선 에 의해 노화가 유도된 섬유아세포에서 브라질린의 항노화 효능을 확인하기 위해서 브라질린의 농도별 세포 생존율, $\mathrm{mRNA}$ 의 발현 양상, 1 형 콜라겐 및 MMP1 단백질의 생성 정도를 확인하였다. 결과: 브라질린의 항노화 효과를 확인하기 위하여 $C O L 1 A 1, C O L 3 A 1, M M P 1$ 의 유전자 발현을 확인한 결과, 자외선에 의해 감소한 COL1A1과 COL3A1 유전자의 발현이 브 라질린에 의해 각각 2 배, 2.25 배 증가하였다. 반면 자외선에 의해 증가한 $M M P 1$ 유전자의 발현은 브라질린에 의해 $75 \%$ 감 소하였다. 섬유아세포의 항산화효소인 $S O D 3$ 의 유전자 발현은 브라질린에 의해 23.5배 증가함을 확인하였다. 또한 1형 콜라 겐 단백질의 생성이 브라질린에 의해 $23 \%$ 가량 증가하였고 MMP1은 $30 \%$ 감소함을 확인하였다. 따라서 본 연구자는 브라질 린의 항노화 효능 및 항산화능을 확인하였다. 결론: 본 연구결과를 통하여 브라질린의 항노화 효능을 확인하였고, 향후 브라질린이 화장품 및 건강식품과 의약품의 개발에 응용 될 수 있는 소재로서의 가능성을 확인하기 위해 추가적인 기전연구가 필요할 것으로 생각된다.

핵심어: Brazilin, 항노화, COL1A1, MMP1, SOD3

이 논문은 2015학년도 세명대학교 교내학술연구비 지원에 의해 수행된 연구임.

\section{참고문헌}

윤영민, 배승희, 안성관, 최용범, 안규중, 안인숙. 자외선(Ultraviolet)이 피부 및 피부세포 내 신호전달체계에 미치는 영향. 아시안뷰티화장품학술지, 11: 417-426, 2013.

이혜영, 김귀정, 김영순, 이성내, 이성옥. 피부과학. 군자출판사, 파주, pp20-24, 2007. 


\section{中文摘要}

\section{Brazilin对紫外线照射而诱导衰老的真皮纤维细胞的抗老化效能}

\section{沁重鉉}

世明大学校 韓方化粧品科學科, 忠淸北道 堤川市, 韩国

目的: 研究brazilin对紫外线照射而衰老的真皮纤维细胞的抗老化作用。方法: 为了研究brazilin对紫外线照射而诱导抗衰 的真皮纤维细胞的抗老化作用, 研究了不同浓度的brazilin对真皮纤维细胞生存率影响以及对真皮纤维细胞的mRNA表 达、胶原蛋白、I型及MMP1蛋白质的形成程度的影响。结果: 为了确认brazilin的抗衰老效果, 分析 COL1A1, COL3A1, MMP1的遗传因子的表达, 其结果如下 : 用brazilin处理之后, 因紫外线而减少的 COL1A1和 COL3A1的遗传因子的表达, 分别提高了2倍和2.5倍；而因紫外线而增加的 MMP1遗传因子的表达反而减少了75\% ; 纤维细胞的抗氧化酶 SOD3的遗 传因子的表达也提高了2.35倍; 胶原蛋白，I型蛋白质的形成也增加了 $23 \%$ ，而MMP1反而减少了 $30 \%$ 。通过以上结果确 认了brazilin的抗衰老及抗氧化作用。结论: 通过研究, 确认了brazilin的抗衰老作用, 进一步确认brazilin在化妆品、健康 食品以及医药品中的应用可行性, 必须对brazilin进一步进行深度研究。

关键词: Brazilin，抗衰老，COL1A1，MMP1，SOD3 
